\title{
Seedlings from marginal and core populations of European beech (Fagus sylvatica L.) respond differently to imposed drought and shade
}

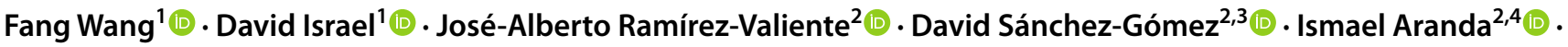 \\ Pedro J. Aphalo ${ }^{1}$ (D) T. Matthew Robson ${ }^{1}$ (i)
}

Received: 27 April 2020 / Accepted: 13 July 2020 / Published online: 20 July 2020

(c) The Author(s) 2020

\begin{abstract}
Key message Local adaptation largely segregates between traits affecting light responses and water relations, but population-level differences in stomatal conductance when growth is unconstrained converge among populations under water stress.

Abstract Warming temperatures and altered precipitation patterns threaten plant populations worldwide. European beech (Fagus sylvatica) is a species that expresses both high phenotypic plasticity and local adaptation among populations. Beech seedlings' susceptibility to prolonged drought may be dictated by their immediate light environment. We tested whether seedlings of four beech provenances, from contrasting edaphoclimatic environments, expressed differences in trait responses to imposed water stress under sun and shade treatments. Populations from the southern range margin were expected to display greater water-stress tolerance and core populations' faster growth rates in the absence of abiotic limitations. Both high light and water stress induced differences in trait responses among provenances, but traits that failed to respond to our experimental treatments likewise did not segregate at the provenance level. Hence, those traits responding to light, e.g., increasing leaf flavonol index and leaf mass area, also tended to differ among provenances. Similarly, there was evidence of local adaptation among provenances in traits, like midday leaf water potential, responding to water stress. Exceptionally, there was a three way interaction water- $\times$-light- $\times$-provenance for stomatal conductance which converged among provenances under water stress. Leaf chlorophyll content also varied both with light and water in a provenance-specific manner. We found core provenances' growth traits to outperform others under favourable conditions, whereas southern and high-elevation populations displayed traits adapted to tolerate high irradiance. Only stomatal conductance produced a complementary interactive response between light- $X$-water across provenances, whereas other traits responded less to combined water stress and high irradiance than to either treatment alone.
\end{abstract}

Keywords Local adaptation $\cdot$ Phenotypic plasticity $\cdot$ Photoprotection $\cdot$ Climate change $\cdot$ Provenance trial $\cdot$ Drought stress

\section{Introduction}

Communicated by Wieser.

Electronic supplementary material The online version of this article (https://doi.org/10.1007/s00468-020-02011-9) contains supplementary material, which is available to authorized users.

T. Matthew Robson

matthew.robson@helsinki.fi

1 Evolutionary and Organismal Biology (OEB), Viikki Plant Science Centre (ViPS), University of Helsinki, P.O. Box 65, 00014 Helsinki, Finland

2 Centro de Investigación Forestal (INIA-CIFOR), Instituto Nacional de Investigación y Tecnología Agraria y Alimentaria, Carretera Coruña Km 7.5, 28040 Madrid, Spain
Climate change across Europe is expected to drive the northwards range shift of tree species, due largely to warmer and drier conditions, facilitating better growth of populations at

3 Centro de Investigación Agroforestal de Albaladejito (CIAF), Instituto Regional de Investigación, Desarrollo Agroalimentario y Forestal de Castilla-La Mancha (IRIAF), Carretera Toledo-Cuenca, Km 174, 16194 Cuenca, Spain

4 Instituto de Investigaciones Agroambientales y de Economía del Agua (INAGEA), Palma de Mallorca, Islas Baleares, Spain 
the leading range-edge but increasing the likelihood of mortality at the trailing range-edge (Pulido et al. 2019; Archambeau et al. 2020; Fréjaville et al. 2020). The consequences for species like Fagus sylvatica L. (henceforth beech) are of particular interest, as beech is an ecologically, culturally and commercially important species with a wide geographical distribution across Europe. To implement actions to mitigate effects of climate change, we should strive to understand processes underpinning plant fitness, including the relative importance of phenotypic plasticity and local adaptation to the sorts of environmental stresses that species are predicted to experience (Valladares et al. 2014). As seedlings are typically less able to resist stress than adult trees, the most important environmental filters act during the recruitment of tree seedlings into a population (Fraaije et al. 2015). Thus, studies on seedlings can provide relevant information on the eco-evolutive characteristics of populations in an adaptive context.

Tree seedlings often establish in an environment, where they are exposed to multiple chronic stresses. Although shade-tolerance in beech at the species level confers crosstolerance, allowing trees to survive better under some environmental stresses (Valladares et al. 2007), this does not always apply to shade and drought which can interact to produce an antagonistic effect on the morphological and physiological acclimation responses of tree seedlings (Niinemets 2010). Potential antagonism in these functionaltrait responses to combined water-and-light limitation can impede the recruitment of beech seedlings (Aranda et al. 2005; Robson et al. 2009). Two scenarios for the action of seasonal drought in forest understoreys are: (1) that in sunny canopy gaps, high evaporative demand and irradiance favour high photosynthetic rates but accompanied by water loss and photoinhibition, and (2) that in shaded understorey environments, carbon starvation can occur when stomata remain closed to maintain plant water balance under severe drought stress (Aranda et al. 2001), and respiratory losses exceed carbon gained through photosynthesis (Valladares and Niinemets 2008; Rodriguez-Calcerrada et al. 2010; Arend et al. 2016). Nevertheless, in arid environments, shade can sometimes benefit woody saplings (e.g., Pistacia and Quercus) by reducing leaf temperatures and photoinhibition, and promoting shade phenotypes that are typically better adapted to survive drought than sun phenotypes, despite the larger initial decreases in photochemical efficiency they suffer under equivalent drought stress (Valladares et al. 2005).

As a late-successional forest species, beech is shade-tolerant and relatively slow growing. It maintains a seedling bank in deep understorey shade, exploiting gaps or lighter shade providing favourable conditions for promotion to the canopy (Collet et al. 2002; Annighöfer et al. 2017). These increases in sunlight reaching the understorey provide the irradiance required to increase photosynthetic carbon gain, and physiological and morphological acclimation, as well as biochemical photoprotection, increasing cross-tolerance to environmental stressors (Tognetti et al. 1998; Scartazza et al. 2016). The relatively conservative functional strategy and shallow-rooting growth habit of beech means that the species is often considered vulnerable to changes in climate, in particular increased summer droughts (Jump et al. 2006; Geßler et al. 2006; Piovesan et al. 2008). Earlier research has shown that despite its shade tolerance, beech seedling mortality can be higher in understorey shade than sun-patches under drought conditions (Valladares and Pearcy 2002; Robson et al. 2009). This is thought to be either because of (1) greater soil drought in understorey shade due to the proximity of large trees' roots, (2) lower relative allocation to roots in the shade than in the sun, (3) the inability to utilise understorey sunflecks for carbon fixation due to restrictions on stomatal opening under drought, or (4) a functional trade-off limiting the capacity of phenotypes acclimated to shade to deploy drought avoidance mechanisms; reducing hydraulic conductivity through morphological acclimation and by increasing intrinsic water use efficiency (Aranda et al. 2001; Robson et al. 2009; Bartlett et al. 2012).

European beech has an interesting biogeographical history as it was eliminated from much of Europe during the last glaciation, apart from sheltered refugia around the Mediterranean and in the Balkans (Magri 2008; Tegel et al. 2014), from where it subsequently recolonised during the Holocene spreading from the south east of Europe (Giesecke et al. 2006). This has led to a highly structured genetic diversity across the current range, which stretches from central Spain in the south-west of Europe to Sweden in the north, and Poland and Ukraine in the east (Paule et al. 1984). This diversity is evident from neutral and adaptive molecular markers (e.g., Carsjens et al. 2014; Gömöry et al. 2015; Bontemps et al. 2016). Provenances may also differ in their phenotypic plasticity in acclimation to drought, which is typically evident through leaf traits affecting gas exchange and plant water status (Robson et al. 2012; Sánchez-Gómez et al. 2013). The origin of different beech provenances can also affect seedling performance because of interactions with the microbiome of soil communities (Manzanedo et al. 2018), feeding back to effect drought tolerance. Besides location, the elevation of origin affects a suite of leaf-level traits related to stress tolerance and photosynthesis, as found in a comparison of five beech provenances along an elevational gradient in Czechia (Kučerová et al. 2018). Intraspecific differences in strategy involving trade-offs between growth and defense or stress tolerance are also visible in the metabolite profiles of leaves across beech provenances (Aranda et al. 2017). This variability can result from differences in the amount and composition of solar radiation received at their environment of origin, and even from differences in exposure to ultraviolet radiation (UV) (Neitzke and Therburg 
2003). However, knowledge about the dynamics and drivers of secondary-compound accumulation in different beech population is sparse.

Our objective was to identify the processes underpinning the capacity of beech seedlings from populations of different origin to resist drought stress at high and low irradiances. To do this, we performed an experiment under semi-controlled conditions over one growing season, to test how imposed drought and sun-shade treatments affected plant traits indicative of water status, photoprotection and carbon assimilation in seedlings of Fagus sylvatica. We selected populations originating from four contrasting environments to grow under near-ambient temperature and radiation regimes in Helsinki, southern Finland. This also allowed us to test the extent of local adaptation in drought response across marginal and range-core populations. In general, marginal plant populations are expected to express greater stress tolerance, in a trade off against poorer performance in terms of maximum growth rate without stress (Rose et al. 2009; Bontemps et al. 2016). Accordingly, we tested the following hypotheses:

- We expected the provenance from the southern rangelimit to perform best under water limitation because of its high physiological plasticity to acclimate to drought stress, in both sun and shade conditions (Hypothesis 1).

- From the core of beech distribution, we expected a faster growth rate and greater drought tolerance from the low-elevation provenance; but higher constitutive photoprotection, expressed as greater accumulation of UV-screening epidermal flavanols and hydroxycinnamic acids (HCA), in the provenance from high elevation (Hypothesis 2).

- The degree of stress tolerance might also reflect likelihood to migrate to higher elevations under climate change; a scenario sometimes predicted for beech populations (Sabaté et al. 2002). Low photosynthetic rates and stomatal conductances under stressful summer conditions, of high evaporative demand and low soil moisture, have previously been reported for northern range-edge provenances compared to the other beech populations (Aranda et al. 2012; Robson et al. 2012; Sánchez-Gómez et al. 2013). Hence, we expected the provenance from the northern range margin to have the lowest capacity to cope with drought stress during this experiment, reflected in lower photosynthetic rates in the sun and poorest control of water loss in general (Hypothesis 3).

\section{Materials and methods}

\section{Plant material and experimental conditions}

Four European beech (Fagus sylvatica) provenances from contrasting environments spanning a wide latitudinal gradient covering the species range were used in the experiment. Beechnuts were collected in autumn preceding the experiment from at least 20 trees per population and stored over winter in Helsinki. A relict population from the ancient beech forest of Montejo de la Sierra to the north of Madrid province (Montejo-ES) represented the south-westerly range margin of beech distribution. A population was chosen from Blaviksliarna, Simlangsdalen, in southern Sweden at the northern range margin of beech distribution (Blaviksliarna$\mathrm{SE})$. Two provenances were chosen from the core beech distribution in Germany at contrasting elevations: at Eichelberg (Eichelberg-DE, $525 \mathrm{~m}$ a.s.1.) and Rindelpholz (RindelpholzDE, $1175 \mathrm{~m}$ a.s.l) (Table 1).

All beechnuts were cleaned and fully imbibed in water (2nd February), and sown in seed trays of coarse sand, where they were kept moist and stratified at $3{ }^{\circ} \mathrm{C}$ for 8 weeks in a growth room with a photoperiod of 8-h light/16-h darkness. Germination of the four provenances was sequential (Table S1), so to synchronise the seedlings for the start of the experiment, later germinating cohorts were forced in a greenhouse at $20^{\circ} \mathrm{C}$, while early-germinating seedlings were held close to the two-cotyledon stage in cooler temperature conditions in an unheated greenhouse. Germinated seedlings were transplanted to individual tubes $(20-\mathrm{cm}$ length $\times 3.5$ $\mathrm{cm}$ diameter) in a substrate of 3:1 sand:peat containing slow release fertiliser (Osmocote Exact Hi Start:15\% N+4.4\% $\mathrm{P}_{2} \mathrm{O}_{5}+8.3 \% \mathrm{~K}_{2} \mathrm{O}+1.8 \% \mathrm{MgO}+\mathrm{TE}$, Scotts International B.V, Netherlands). During May, at the start of the experimental treatments all seedlings were transferred to an opensided greenhouse with a roof blocking precipitation but transparent to $80 \%$ solar radiation (Table 2 ).

Table 1 Origin of the four beech provenances and climatic conditions at their origin

\begin{tabular}{|c|c|c|c|c|c|}
\hline Provenance name & Latitude & Longitude & Elevation $\mathrm{m}$ a.s.l & $\begin{array}{l}\text { Mean Annual } \\
\text { Temperature }\end{array}$ & $\begin{array}{l}\text { Mean Annual } \\
\text { Precipitation }\end{array}$ \\
\hline Montejo de la Sierra, Spain (Montejo-ES) & N $4101^{\prime}$ & W3 5' & $1400 \mathrm{~m}$ & $9.5^{\circ} \mathrm{C}$ & $1100 \mathrm{~mm}$ \\
\hline Rindelpholz, Germany (Rindelpholz-DE) & N $4729^{\prime \prime \prime}$ & E10 08" & $1175 \mathrm{~m}$ & $4.8^{\circ} \mathrm{C}$ & $2535 \mathrm{~mm}$ \\
\hline Eichelberg, Germany (Eichelberg-DE) & $\mathrm{N} 4855^{\prime}$ & E11 26" & $525 \mathrm{~m}$ & $7.8^{\circ} \mathrm{C}$ & $692 \mathrm{~mm}$ \\
\hline Blaviksliarna, Sweden (Blaviksliarna-SE) & N $5790^{\prime \prime \prime}$ & E13 13' & $75 \mathrm{~m}$ & $6.5^{\circ} \mathrm{C}$ & $860 \mathrm{~mm}$ \\
\hline
\end{tabular}


Table 2 Midday clear (1st June) and cloudy sky (6th June) solar PAR irradiance $\left(\mu \mathrm{mol} \mathrm{m}{ }^{-2}\right)$ under each plot receiving shade and sun treatments

\begin{tabular}{llc}
\hline $\begin{array}{l}\text { Treatment combination } \\
(n=4)\end{array}$ & $\begin{array}{l}\text { Cloudy day at } \\
\text { midday } \\
\text { mean } \pm \text { SE }\end{array}$ & $\begin{array}{l}\text { Sunny day at midday } \\
\text { mean } \pm \text { SE }\end{array}$ \\
\hline Ambient outside & $674 \pm 37$ & $1451 \pm 74$ \\
Shade dry & $284 \pm 52$ & $311 \pm 50$ \\
Shade wet & $237 \pm 48$ & $315 \pm 77$ \\
Sun dry & $594 \pm 77$ & $1222 \pm 187$ \\
Sun wet & $561 \pm 72$ & $1073 \pm 203$ \\
\hline
\end{tabular}

Measured with a calibrated quantum sensor (LICOR 190). Each measurement is an average over 15-s intervals. Mean \pm SE of four replicates of each treatment combination, within each replicate several measurements were made to capture the spatial variation in irradiance within a plot

In total 350 seedlings of similar height at the two-leaf stage were selected for use in the experiment and an equal number of seedlings from each provenance were allocated at random to each of eight "plots" (Fig. S1). The main plot factor was light treatment, and four replicate plots received near-ambient sunlight ("Sun"), while seedlings in four identical plots grew under a double-thickness of neutral shade cloth (Varjostuspeite K-Garden, Finland), where they received about 20-25\% of ambient solar radiation ("Shade"). Light treatments were checked by measurements of photosynthetically active radiation (PAR) with a calibrated quantum sensor (LICOR 190, Li-Cor Inc., Lincoln, NE, USA): mean midday clear-sky solar spectral irradiance $\left(\mu \mathrm{mol} \mathrm{m} \mathrm{m}^{-2}\right)$ under the treatments was $1147 \mu$ mol photons $\mathrm{m}^{-2} \mathrm{~s}^{-1}$ Sun and $313 \mu \mathrm{mol}$ photons $\mathrm{m}^{-2} \mathrm{~s}^{-1}$ Shade on 1 st June (Table 2). The watering treatment was a split-plot factor: half of the seedlings in each plot from both the Sun and Shade treatments were well watered ("Wet"), while the other half were subject to a water-limited treatment ("Dry") lasting from the start of the experiment on 24th May throughout the summer until mid-September. Soil moisture content was monitored both prior to and after watering throughout the experiment using a TDR probe (SM200 Moisture Sensor with HH2 Moisture Meter, Delta-T Devices, Cambridge, UK). This gave a $\% v / v$ soil moisture which could be expressed as soil water potential $\left(\Psi_{\text {soil }}\right)$ using a calibration curve for the specific substrate mixture used in the experiment. A measured volume of water (usually 10-20 ml) was administered to each pot every 2-3 days to maintain soil moisture content at $10-15 \% v / v$ in the dry treatment, and $20-35 \% v / v$ in the Wet treatment (Fig. S2). The average temperature and relative humidity every $10 \mathrm{~min}$ throughout the experiment was monitored in each plot with an ibutton sensor (Maxim Integrated, San Jose, CA, USA; Fig. S3). The relative performance of seedlings from each provenance under each of the treatment combinations was compared through the summer by monitoring growth, leaf gas exchange, absorption by leaf pigments and leaf water potential.

\section{Gas exchange measurements}

The leaf-level photosynthetic rate and stomatal conductance were measured with a portable Infra-Red Gas Analyser (IRGA LICOR 6400; leaf chamber $2-\times-3 \mathrm{~cm}$; Li-Cor Inc., Lincoln, NE, USA). Measurements were taken on sunny days in late July (22nd, 23rd, 26th and 27th July) at mid-late morning (10:00-12:00) when photosynthetic rate was expected to be at its daily maximum. In total 340 measurements of light-saturated gas exchange were made from seedlings in each of the four replicate plots (up to 20 per provenance-treatment combination). Measured leaves received $1200 \mu \mathrm{mol}$ photons $\mathrm{m}^{-2} \mathrm{~s}^{-1}$ PAR, provided by a LICOR6400-02B red-blue light source: this value was considered light-saturating as it exceeded the maximum light received by leaves at midday in the Sun and Shade treatments (Table 2). Set conditions in the leaf chamber were: flow rate $700 \mu \mathrm{mol} \mathrm{s}^{-1},\left[\mathrm{CO}_{2}\right] 380 \mathrm{ppm}$, c. $30 \%$ Relative Humidity (RH), equivalent to vapour pressure deficit (VPD) $2.4 \mathrm{kPa}$, and block temperature $22.1{ }^{\circ} \mathrm{C}$, giving an air temperature of $23-24{ }^{\circ} \mathrm{C}$. Measurements were recorded when the photosynthesis $\left(A_{\text {net }}\right)$, stomatal conductance $\left(g_{\mathrm{s}}\right)$, and internal carbon dioxide $\left(C_{\mathrm{i}}\right)$ were stable. Additional parameters from the gas exchange measurements were calculated: the ratio of internal to ambient $\mathrm{CO}_{2}$ concentration $\left(C_{\mathrm{i}} / C_{\mathrm{a}}\right)$, transpiration rate $\left(E_{\mathrm{wv}}\right)$ and the instantaneous water use efficiency (IWUE $A_{\text {net }} / g_{\mathrm{s}}$ ).

\section{Leaf water potential measurements}

The midday leaf water potential $\left(\Psi_{\text {midday }}\right)$ was measured on the 3 rd or 4 th leaves produced by seedlings from each of the 4 replicate plots (in total c. 20 plants per provenancetreatment combination) on cloud-free days at midday on the same late July days as gas exchange measurements. These leaves had not been shaded by others and were excised at the petiole, recut with a scalpel, and their water potential immediately measured using a pressure chamber (model 1000; PMS Instrument Co., Albany, OR, USA). The specific soilleaf hydraulic conductance $\left(K_{\mathrm{L}}\right)$ was estimated from water potential and gas exchange measurements as

$K_{\mathrm{L}}=E_{\mathrm{wv}} /\left(\Psi_{\text {soil }}-\Psi_{\text {midday }}\right)$.

Soil water potential $\left(\Psi_{\text {soil }}\right)$ measured, as described above, on the same morning as physiological measurements was used as a substitute for leaf pre-dawn water potential in the calculation of water potential difference ( $\left.\Psi_{\text {diff }}=\Psi_{\text {soil }}-\Psi_{\text {midday }}\right)$, because the near-24-h daylength and small number of leaves per seedlings made it 
impractical to measure pre-dawn leaf water potential. This relies on the assumption that pre-dawn soil water potential and pre-dawn leaf water potentials of beech seedlings are expected to be approximately in equilibrium (Sack and Holbrook 2006; Rose et al. 2009; Bolte et al. 2016), and thus the water potential difference ( $\left.\Psi_{\text {diff }}\right)$ to $\Psi_{\text {midday }}$ can be interpreted as a coarse proxy for the leaf water potential adjustment between the daily minimum and maximum water loss.

\section{Measurements of leaf and seedling growth and photoprotection}

Growth measurements were made immediately prior to the experiment (23rd May) and on four occasions during the experiment (1st June, 28th June, 16th July, 19th August). Each set of measurements included seedling height, number of leaves, and number of branches of all seedlings in the experiment and leaf size (length and width) of the second leaf produced. Any variation in leaf colour, shape or injury was noted at the same time as these measurements. Leaf and seedling growth rates were calculated as the best fit to a polynomial function. At the end of the experiment (19th August), measured leaves were sampled for calculation of leaf mass area (LMA) from the oven-dried mass of leaves and fresh leaf area of scanned leaves (Image-J, following Wang 2016).

An optical index was recorded of leaf adaxial epidermal flavonols (Dualex 3.3 FLAV, Force-A, Paris, France-reference at $375 \mathrm{~nm}$ ) three times during the experiment: Date 1 (June 1st), Date 2 (29th June and 3rd July), and Date 3 (14th July). At Date 1 and Date 3, an optical index of chlorophyll content (SPAD Konica Minolta 502 chlorophyll meter, Tokyo, Japan) was also recorded, and on Dates 2 and 3 an optical index of hydroxy-cinnamic acids (Dualex HCA, Force-A—reference at $315 \mathrm{~nm}$ ) was recorded.

\section{Statistical analysis}

Effects of provenance and light conditions (Sun/Shade) considered as the main plot factors, and water stress (Dry/Wet) as a split-plot factor, were assessed using a mixed model ANOVA, where a pair of adjacent plots were considered a block (random factor: nested with light and water treatments). There were four replicate pairs of light treatments within the greenhouse, each containing both Wet and Dry treatments (Table S1). ANOVA were run using LMER function from package lme4 fitted using REML. Significant twoway interactions were further tested with function glht from package "multicomp" using Holm's adjustment for multiple comparisons (R version 3.4.3, R Core Team 2019).

\section{Results}

\section{Gas exchange measurements}

Our water stress treatment (Dry) decreased photosynthesis $A_{\text {net }}(p<0.001)$ similarly in all provenances, from approximately $12 \mu \mathrm{mol} \mathrm{m}^{-2} \mathrm{~s}^{-1}$ in the well-watered (Wet) treatment to $2.5 \mu \mathrm{mol} \mathrm{m} \mathrm{m}^{-2} \mathrm{~s}^{-1}$ in the Dry treatment (Fig. 1; Table 3a). There was also an interaction effect of the combination of light and water treatments (Light $\times$ Water, $p=0.006$ ) which followed a similar pattern in all provenances: in the wet treatment, light-saturated $A_{\text {net }}$ was higher in seedlings grown under full sun than those under shade, whereas in the Dry the pattern was reversed. It is worth noting here that the absence of shading provoked fluctuations in temperature and relative humidity in the Sun treatments that is likely, when combined with the imposed water-stress, to have increased the intensity of drought compared with Shade plots (Fig. S3), with likely consequences for the traits of seedlings therein. The $A_{\text {net }}$ differed among provenances under the light treatments (Light $\times$ Provenance, $p=0.028$ ), whereby the largest difference in $A_{\text {net }}$ between Sun-Wet and Shade-Wet was in Montejo-ES and the smallest difference in Eichelberg-DE (Fig. 1, 1st row; Table 3a).

Patterns in stomatal conductance $\left(g_{\mathrm{s}}\right)$ among treatments closely mirrored those of $A_{\text {net }}$. The Dry treatment caused drastic stomatal closure $(p<0.001)$, e.g., from $g_{\mathrm{s}}$ of 227 to $46 \mathrm{mmol} \mathrm{m}^{-2} \mathrm{~s}^{-1}$ in Shade (Fig. 1, 2nd row). Light affected $g_{\mathrm{s}}$ differently under the two watering treatments (Light $\times$ Water, $p=0.009)$ and differently among provenances (Light $\times$ Provenance, $p=0.022$ ), and the three way interaction of Light $\times$ Water $\times$ Provenance was significant ( $p=0.033$; Fig. 1, 2nd row; Table 3a). Montejo-ES seedlings produced the largest difference in $g_{\mathrm{s}}$ from Sun and Shade treatments in the Wet. In the Dry treatments, $g_{\mathrm{s}}$ was lower among seedlings in the Sun than those in the Shade, and differences among provenances were not as distinct as under the wet treatments; although in Blaviksliarna-SE the Sun-Dry $g_{\mathrm{s}}$ was highest (Fig. S4 for detailed $g_{\mathrm{s}}$ of Dry treatments expanded from Fig. 1, 2nd row). Sensitivity of $g_{\mathrm{s}}$ to soil moisture was similar among provenances in Shade, but in the Sun where it increased most readily in seedlings from Blaviksliarna-SE, and least in Montejo-ES, when released from water stress (Fig. 1; Fig. S5).

The $C_{\mathrm{i}} / C_{\mathrm{a}}$ was consistently higher in the wet treatments than the dry treatments $(p<0.001)$, within which $C_{\mathrm{i}} / C_{\mathrm{a}}$ was lower in the Shade-Dry than the Sun-Dry, even though $g_{\mathrm{s}}$ was higher in the Shade-Dry. Under well-watered conditions, the biggest sun-shade difference in $C_{\mathrm{i}} / C_{\mathrm{a}}$ was in Blaviksliarna-SE (Fig. 1, 3rd row). As would be expected, water use efficiency (IWUE) was highest under Dry 
Fig. 1 Gas exchange measured by IRGA at midmorning over the period 23rd-27th July. Means \pm 1 SE of 4 replicate plots for treatments combinations for each of the four provenances: (1st row) $A_{\text {net, }}$ (2nd row) $g_{\mathrm{s}}$ (3rd row) $C_{\mathrm{i}} / C_{\mathrm{a}}$ (4th row) IWUE. See Fig. S4 for zoom-in of $g_{\mathrm{s}}$ Dry treatments
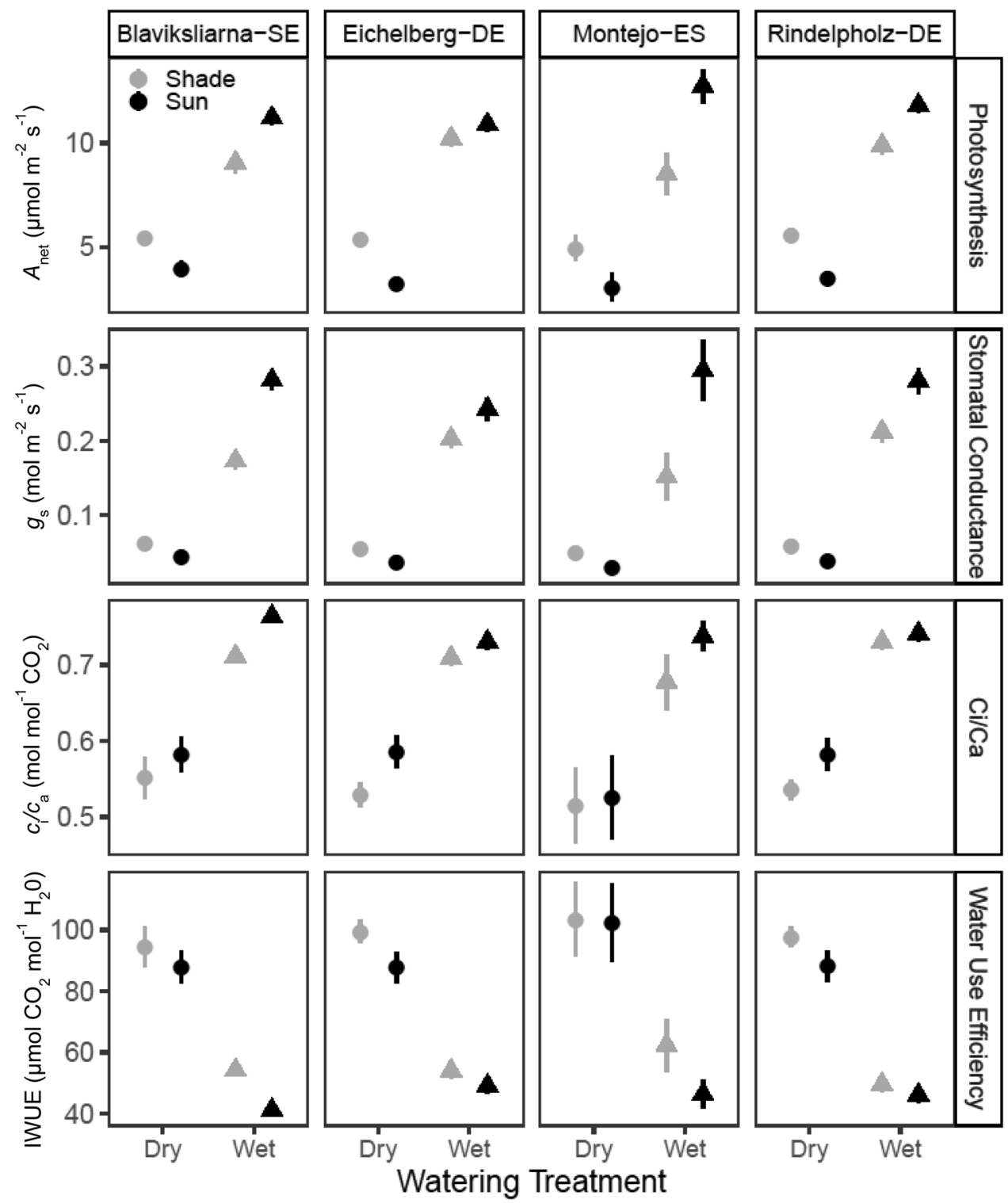

conditions $(p<0.001)$, but differences among provenances were negligible (Fig. 1, 4th row; Table 3a).

\section{Water relations}

Midday leaf water potentials ( $\left.\Psi_{\text {midday }}\right)$ were higher under Wet than Dry treatments $(p=0.003)$, and lower under Sun vs. Shade treatments $(p=0.050)$; although the latter difference was largely due a reduction in $\Psi_{\text {midday }}$ in Sun-Wet compared to Shade-Wet seedlings, which reached similar $\Psi_{\text {midday }}$ values to Sun-Dry seedlings in all but the MontejoES provenance (Water $\times$ Provenance, $p=0.017$; Table $3 \mathrm{a}$ ). Seedlings from Montejo-ES reached lower $\Psi_{\text {midday }}$ in the Dry treatment than the other provenances, which were otherwise similar in their $\Psi_{\text {midday }}$ (Fig. 2, 1st row, Table 3a). General patterns in $\Psi_{\text {diff }}$ (not shown) mainly tracked $\Psi_{\text {midday }}$ within each of wet and dry treatments, with only minor effects of variation in pre-dawn soil water potential.

The apparent soil-leaf hydraulic conductance $\left(K_{\mathrm{L}}\right)$ in the Shade treatments was $0.5 \mathrm{~mol} \mathrm{~m}^{-2} \mathrm{~s}^{-1} \mathrm{MPa}^{-1}$ higher overall than that in the Sun $(p=0.040) ;$ a $27 \%$ increase. In the Wet treatment, $K_{\mathrm{L}}$ was $2.3 \mathrm{~mol} \mathrm{~m}^{-2} \mathrm{~s}^{-1} \mathrm{MPa}^{-1}$ higher, an increase of $4-5$ times more than that in the Dry $(p<0.001)$, but the differences in $K_{\mathrm{L}}$ among the provenances were negligible (Fig. 2, 2nd row, Table 3a, $p=0.672$ ).

\section{Leaf pigments}

Leaf chlorophyll content per unit area (LCC) increased during the 6 weeks between June 1st (Date 1) and July 14th (Date 3). It also remained significantly higher in the Shade than the Sun treatment (Fig. 3, 1st row, Table 3b, $p=0.001$ ). 
Table 3 Results of ANOVA for response traits

\begin{tabular}{|c|c|c|c|c|}
\hline Parameter & Light (L) & Water (W) & Provenance $(\mathrm{P})$ & Significant Interactions \\
\hline \multicolumn{5}{|c|}{ (a) Gas exchange and water relations } \\
\hline$A_{\text {net }}$ & $F=0.1 P=0.777$ & $F=172.1 P<0.001$ & $F=1.2 P=0.349$ & $\begin{array}{l}\mathbf{L}: \mathbf{W} F=16.7 \boldsymbol{P}=\mathbf{0 . 0 0 6} \\
\mathbf{L}: \mathbf{P} F=3.8 \boldsymbol{P}=\mathbf{0 . 0 2 8}\end{array}$ \\
\hline$g_{\mathrm{s}}$ & $F=0.8 P=0.394$ & $F=284.8 P<0.001$ & $F=1.4 P=0.275$ & $\begin{array}{l}\text { L:W } F=14.2 P=0.009 \\
\text { L:P } F=4.1 P=0.022 \\
\text { L:W:P } F=3.6 P=0.033\end{array}$ \\
\hline$C_{\mathrm{i}} / C_{\mathrm{a}}$ & $F=1.0 P=0.364$ & $F=53.1 P<0.001$ & $F=1.9 P=0.174$ & \\
\hline WUE & $F=0.6 P=0.457$ & $F=54.1 P<0.001$ & $F=1.9 P=0.179$ & \\
\hline$\Psi_{\mathrm{md}}$ & $F=6.3 P=0.046$ & $F=23.1 P=0.003$ & $F=1.0 P=0.416$ & $\mathbf{W}: \mathbf{P} F=4.4 P=0.017$ \\
\hline$\Psi_{\text {diff }}$ & $F=5.3 P=0.061$ & $F=9.7 P=0.021$ & $F=1.0 P=0.411$ & $\mathbf{W}: \mathbf{P} F=4.4 P=0.017$ \\
\hline$K_{\mathrm{L}}$ & $F=6.8 P=0.040$ & $F=142.8 P<0.001$ & $F=0.5 P=0.672$ & \\
\hline \multicolumn{5}{|c|}{ (b) Leaf pigments } \\
\hline \multicolumn{5}{|l|}{$\mathrm{LCC}$} \\
\hline Date Rep 1 & $F=43.5 P=0.001$ & $F=0.2 P=0.686$ & $F=11.0 P<0.001$ & $\mathbf{L}: \mathbf{P} F=4.7 P=0.014$ \\
\hline Date Rep 3 & $F=9.1 P=0.024$ & $F=1.1 P=0.345$ & $F=5.4 P=0.008$ & $\begin{array}{l}\mathbf{L}: \mathbf{P} F=3.9 P=\mathbf{P}=026 \\
\mathbf{W}: \mathbf{P} F=9.1 \boldsymbol{P}=\mathbf{0 . 0 0 1}\end{array}$ \\
\hline \multicolumn{5}{|l|}{$I_{\text {flav }}$} \\
\hline Date Rep 1 & $F=704 P<0.001$ & $F=0 P=0.959$ & $F=5.7 P=0.006$ & $\mathbf{L}: \mathbf{P} F=4.3 P=0.019$ \\
\hline Date Rep 2 & $F=454 P<0.001$ & $F=0.5 P=0.501$ & $F=10.9 P<0.001$ & $\mathbf{L}: \mathbf{P} F=5.0 P=0.011$ \\
\hline Date Rep 3 & $F=1041 P<0.001$ & $F=3.5 P=0.111$ & $F=2.5 \underline{P=0.093}$ & $\mathbf{L}: \mathbf{P} F=3.5 P=0.037$ \\
\hline \multicolumn{5}{|l|}{$I_{\mathrm{HCA}}$} \\
\hline Date Rep 2 & $F=0.1 P=0.732$ & $F=2.6 P=0.157$ & $F=12.7 P<0.001$ & $\mathbf{L}: \mathbf{P} F=31.5 P<0.001$ \\
\hline Date Rep 3 & $F=2.0 P=0.208$ & $F=7.3 P=0.036$ & $F=0.3 P=0.838$ & \\
\hline \multicolumn{5}{|l|}{ (c) Growth } \\
\hline \multicolumn{5}{|l|}{ Height } \\
\hline Date Rep 1 & $F=2.2 P=0.189$ & $F=\underline{4.4 \mathrm{P}=0.081}$ & $F=0.7 P=0.567$ & \\
\hline Date Rep 2 & $F=3.5 P=0.112$ & $F=2.9 P=0.138$ & $F=4.1 P=0.022$ & $\begin{array}{l}\mathbf{W}: \mathbf{P} F=3.2 \quad P=0.048 \\
\mathbf{L}: \mathbf{W} F=8.2 \quad \boldsymbol{P}=\mathbf{0 . 0 2 9}\end{array}$ \\
\hline Date Rep 3 & $F=0.5 P=0.511$ & $F=32.6 P=0.001$ & $F=6.3 P=0.004$ & $\begin{array}{l}\mathbf{L}: \mathbf{P} F=6.1 \boldsymbol{P}=\mathbf{0 . 0 0 5} \\
\mathbf{L}: \mathbf{W} F=19 \boldsymbol{P}=\mathbf{0 . 0 0 5}\end{array}$ \\
\hline Date Rep 4 & $F=3.5 P=0.113$ & $F=175 P<0.001$ & $F=4.3 P=0.019$ & $\begin{array}{l}\mathbf{L}: \mathbf{P} F=5.9 P=0.006 \\
\mathbf{L}: \mathbf{W} F=6.7 P=0.041\end{array}$ \\
\hline Date Rep 5 & $F=3.3 P=0.119$ & $F=157 P<0.001$ & $F=5.0 P=0.011$ & $\begin{array}{l}\mathbf{L}: \mathbf{P} F=8.7 \boldsymbol{P}=\mathbf{0 . 0 0 1} \\
\mathbf{W}: \mathbf{P} F=2.5 P=0.096 \\
\mathbf{L}: \mathbf{W} F=2.4 P=0.098\end{array}$ \\
\hline Leaf length & $F=6.0 P=0.049$ & $F=0.3 P=0.634$ & $F=1.9 P=0.167$ & \\
\hline LMA & $F=78.6 P<0.001$ & $F=0.7 P=0.430$ & $F=9.4 P=0.001$ & $\mathbf{L}: \mathbf{W} F=8.9 P=0.025$ \\
\hline \multicolumn{5}{|l|}{ Branching } \\
\hline Date Rep 1 & $F=0.1 P=0.863$ & $F=0.3 P=0.584$ & $F=1.5 P=0.248$ & \\
\hline Date Rep 2 & $F=0.4 P=0.551$ & $F=3.6 P=0.107$ & $F=0.5 P=0.655$ & \\
\hline Date Rep 3 & $F=0.6 P=0.481$ & $F=6.3 P=0.045$ & $F=7.6 P=0.002$ & $\mathbf{W}: \mathbf{P} F=3.6 P=0.034$ \\
\hline Date Rep 4 & $F=9.0 \quad P=0.024$ & $F=42.8 \quad P<0.001$ & $F=13.9 P<0.001$ & $\mathbf{L}: \mathbf{W} F=7.9 P=0.031$ \\
\hline Date Rep 5 & $F=7.2 P=0.036$ & $F=32.9 P<0.001$ & $F=15.7 P<0.001$ & $\begin{array}{l}\mathbf{L}: \mathbf{P} F=5.5 P=\mathbf{P}=007 \\
\mathbf{W}: \mathbf{P} F=3.3 \boldsymbol{P}=\mathbf{0 . 0 4 4}\end{array}$ \\
\hline
\end{tabular}

There was no significant difference in LCC between Dry vs. Wet seedlings, but the Blaviksliarna-SE population had the lowest LCC in the Sun and the two core German provenances, Eichelberg-DE and Rindelpholz-DE, the highest LCC on Date 1 (Light $\times$ Provenance $p=0.14$, Provenance $p<0.001)$. By Date 3, there was also an interaction between the watering treatment and provenance for LCC
(Water $\times$ Provenance $p=0.008$; Fig. 3; Table 3b), whereby Eichelberg-DE had atypically high LCC in the Dry-Shade treatment.

The adaxial epidermal flavonol index $\left(I_{\text {flav }}\right)$, per unit area, in the Sun-Wet treatment remained stable over the three measurement dates, but $I_{\text {flav }}$ declined slightly in the SunDry treatments, and even more so in the shaded seedlings 
Fig. 2 Hydraulic traits measured with a pressure chamber at midday over the period 23rd-27th July. Means \pm 1 SE of 4 replicate plots for treatments combinations for each of the four provenances: (1st row) midday leaf water potential $\left(\Psi_{\text {midday }}\right)$, (2nd row) apparent soil-leaf hydraulic conductance $\left(K_{\mathrm{L}}\right)$. The $y$-axis for $K_{\mathrm{L}}$ follows a logarithmic scale
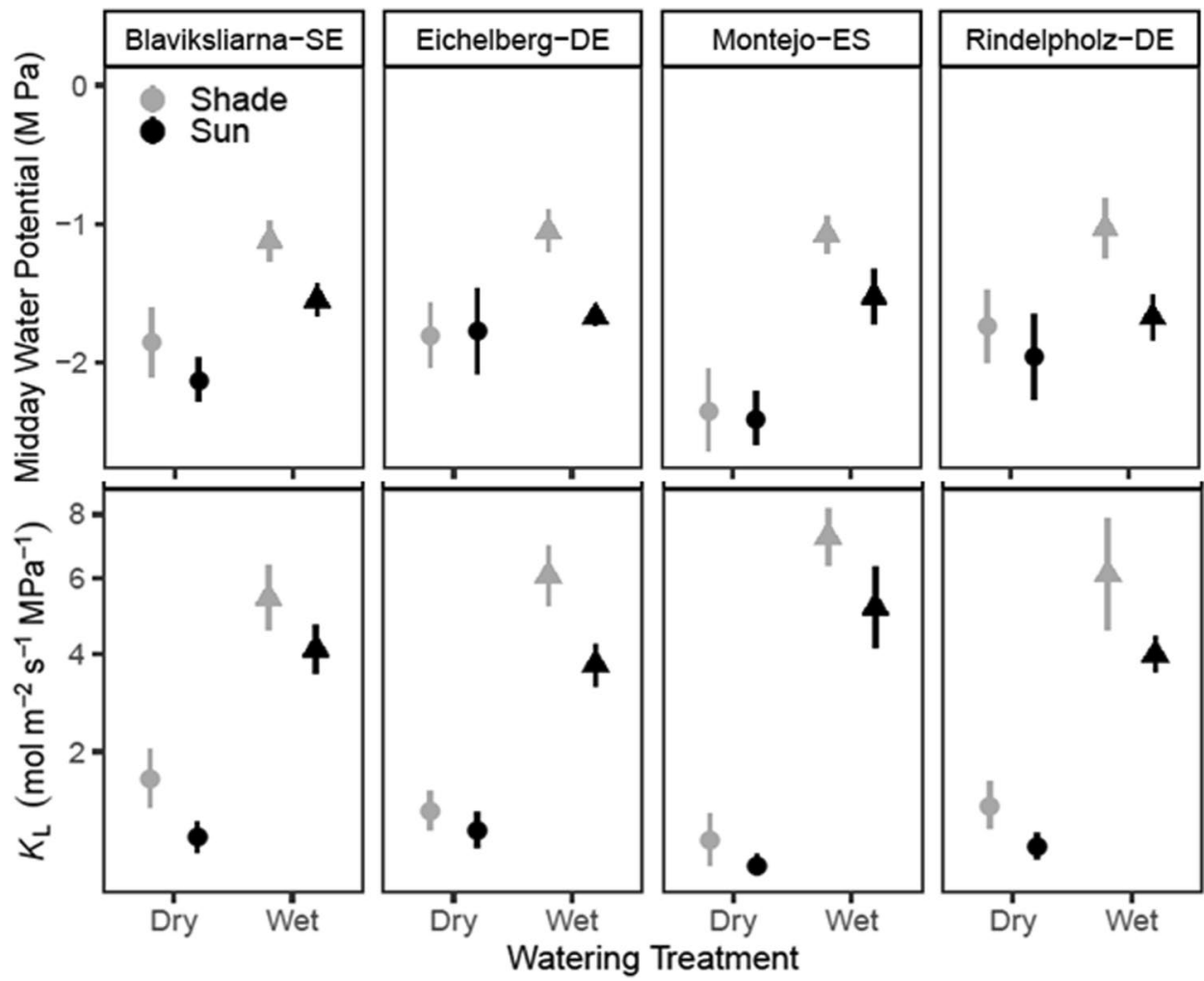

under both watering treatments (Fig. 3, 2nd row, Table 3b). In general, the patterns across light and water treatments remained similar over the three measurement dates, whereby $I_{\text {flav }}$ was mostly higher in the Sun-Wet treatment than the Sun-Dry, and $I_{\text {flav }}$ in the Shade treatments was only half that of the Sun treatments (Light: $p<0.001$ ). A difference in $I_{\text {flav }}$ among provenances was detected under both light treatments on each of the three measurement dates (Light $\times$ Provenance $p=0.019, p=0.011, p=0.037$; Table 3b). Under Shade, Montejo-ES leaves had the highest $I_{\text {flav }}$ of all the provenances, whereas in the Sun, Rindelphlotz-DE and MontejoES were similar, and the latter declined least over time in the Sun-Wet treatment (Fig. 3, 2nd row, Table 3b).

Measurement of the adaxial epidermal HCA index $\left(I_{\mathrm{HCA}}\right)$ was only possible on Date 2 and Date 3. It did not differ significantly with light or watering treatment on Date 2, producing similar values across all treatments averaging 2.0-2.2 (Fig. 3, 3rd row). However, despite the narrow range of values obtained, there was an interaction effect of Light $\times$ Provenance on $I_{\mathrm{HCA}}(p<0.001)$ which followed a similar pattern to that in $I_{\text {flav }}$ On Date 2, the $I_{\mathrm{HCA}}$ in Montejo-ES seedlings was the highest among the provenances in the shade treatments, and that in Eichelberg-DE was lowest of the provenances; but on Date3, increased variability among leaves within each provenance-treatment combination largely obscured any effect among provenances. There was an effect of watering treatment on Date 3 but this appears to derive from decreasing values in some of the shade-dry seedlings, causing increased variability in the results on this date. Visual inspection of the seedlings on 14th July also revealed differences in red-coloration attributable to anthocyanins; red coloration of the youngest leaves was most noticeable in seedlings growing in the Wet treatment in all but the Montejo-ES provenance, where it was entirely absent (Fig. S6, Table 3b).

\section{Growth and morphology}

Seedlings of all provenances continued to grow larger throughout the experiment, growing most overall in the Sun-Wet, followed by the Shade-Wet treatments, in terms of height (Fig. 4, Table 3c), as well as number of leaves and branches (Fig. S7, Table 3c). In the Sun-Dry and ShadeDry treatments most seedlings had similar growth rates, with only Montejo-ES and Eichelberg-DE growing higher in the shade than the sun by the end of the experiment (Fig. 4, significant Light $\times$ Provenance date 3-5, Table 3c). As with the physiological data, this Sun-Shade effect may be partially due to the Dry treatment being slightly less severe in the Shade (Fig. S2).

Leaf length was similar among provenances and treatments, with only sun-shade treatment having a significant effect on leaf length ( $p=0.049$, Fig. 5, 1st row). Overall, the Shade leaves were slightly larger than the Sun leaves. 
Fig. 3 Indices of leaf pigment content per unit area measured by optical leaf-clips (SPAD and Dualex) across three measurements dates. Means $\pm 1 \mathrm{SE}$ of 4 replicate plots for treatments combinations for each of the four provenances: (1st row) leaf chlorophyll content (LCC), (2nd row) leaf adaxial epidermal flavonols (FLAV), (3rd row) leaf adaxial epidermal hydroxycinnamic acids (HCA)
Fig. 4 Time course change in seedling height over the experiment. Seedling height was measured prior to the experiment and on four occasions during the experiment including at final harvest. The vertical dashed line on 24th May represents that start of the experimental treatments. Fitted curves use stat_smooth function to fit a quadratic equation using GLM method $\pm 95 \%$ confident intervals to the mean values from 4 replicate plot for each treatment combination
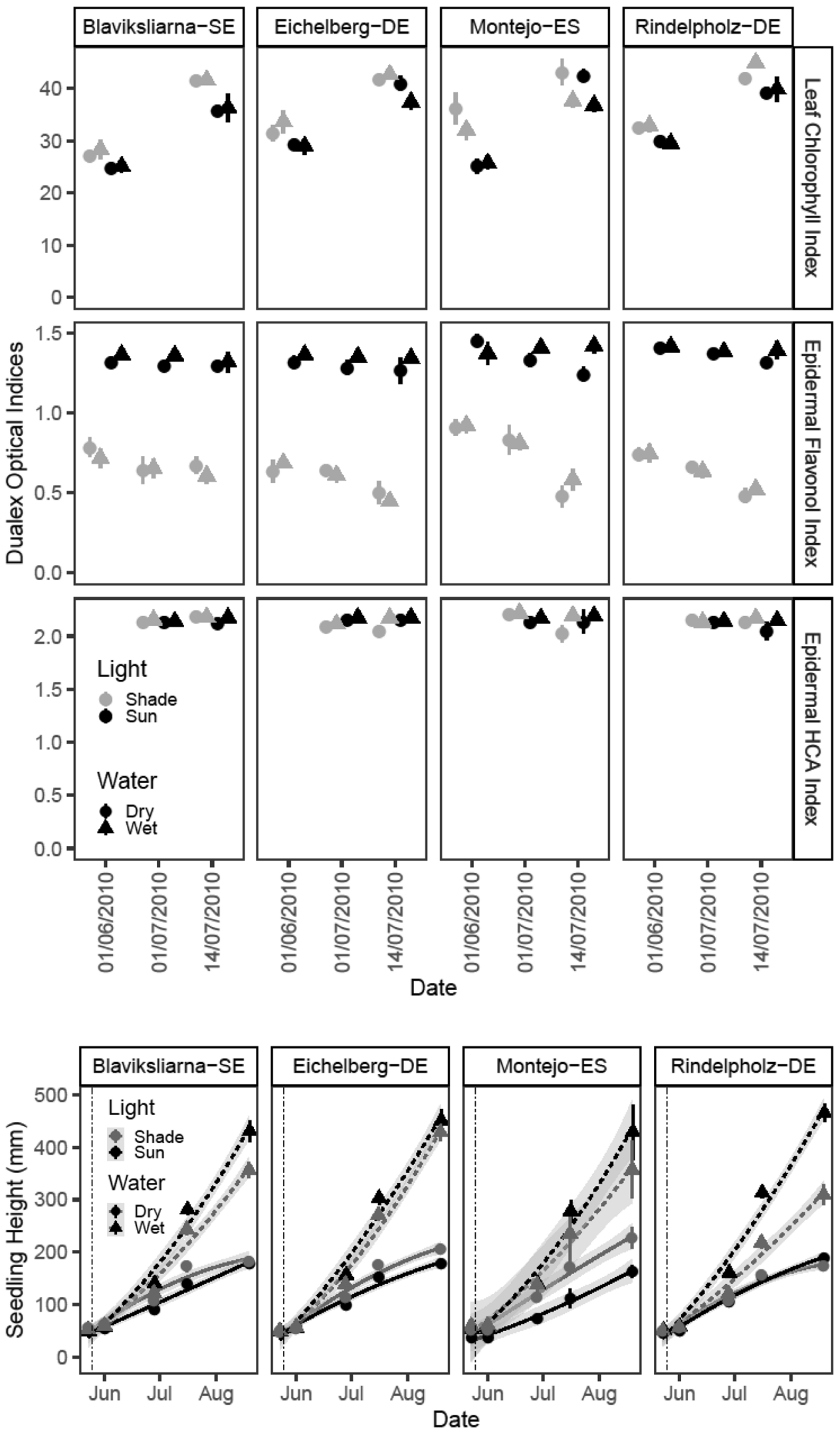
Fig. 5 Leaf morphological traits at the end of the experiment. Means \pm 1 SE of 4 replicate plots for treatments combinations for each of the four provenances: (1st row) leaf length and (2nd row) LMA
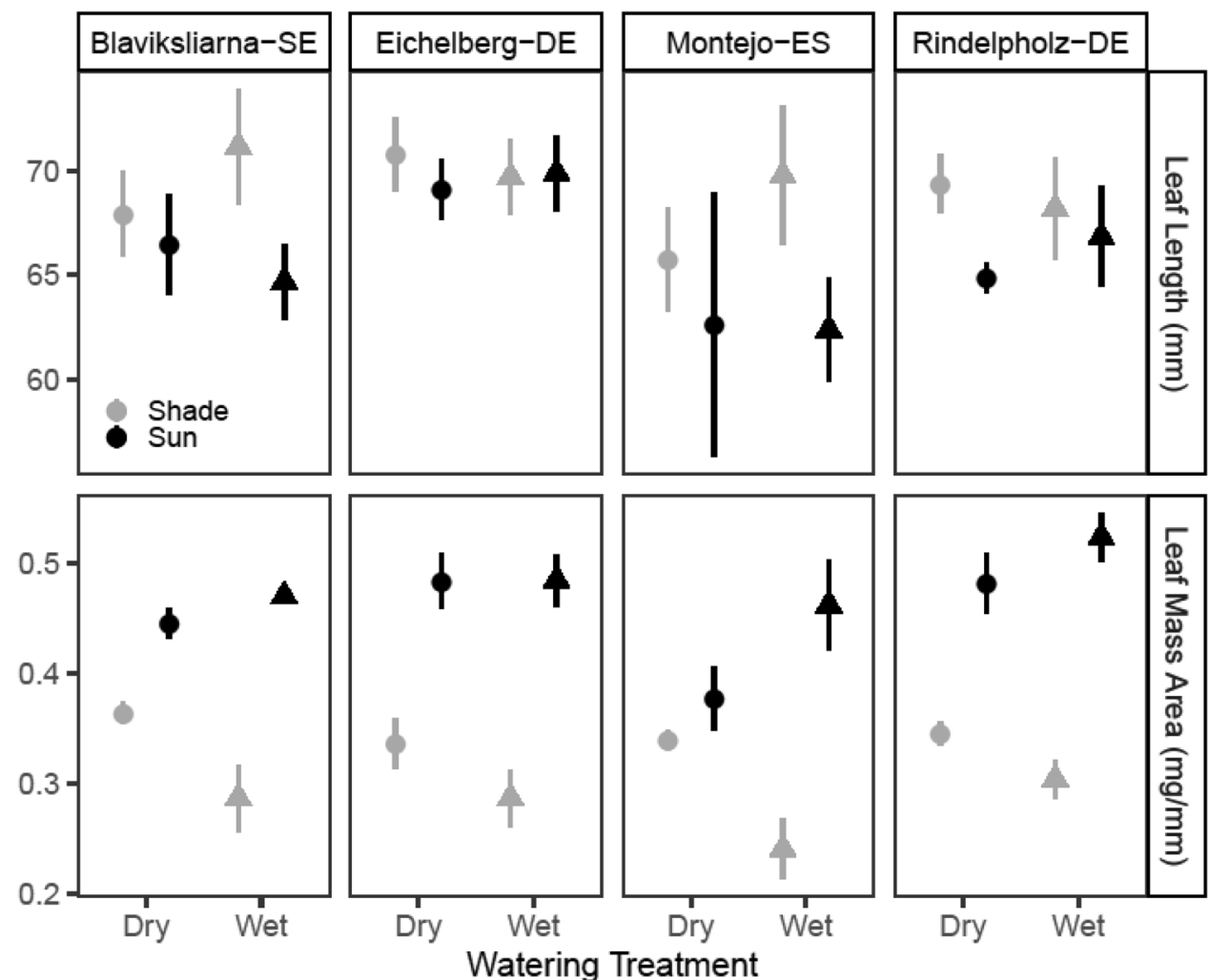

All seedlings had their highest LMA in the Sun treatments ( $p<0.001$, Fig. 5, 2nd row). Of the provenances, MontejoES had the lowest LMA in all treatment combinations (Provenance, $p=0.001$, Table $3 \mathrm{c}$ ). In the shade, there was also an effect of watering treatment on LMA; producing a lower LMA in the Wet than the Dry treatment (Light $\times$ Water, $p=0.025$, Fig. 5; Table 3c). Beyond these effects, there were no significant relationships at the individual-plant level between growth traits and the individual morphological or physiological traits that we measured, such as LCC, $I_{\text {flav }}$ or $K_{\mathrm{L}}$.

\section{Discussion}

Most traits responded to either the water-stress or sun-shade treatment, with only a few traits responding to both. Our water-stress treatments reduced growth, increased water use efficiency and slowed hydraulic conductivity. The effects of sun-shade treatments, on the other hand, were most apparent as changes in leaf morphology and pigments (LCC and $\left.I_{\text {flav }}\right)$; trait responses which also differed among provenances. Interaction effects on traits of sun-shade or watering treatments with provenances were only found when at least one of these main effects was significant. Among provenances, photosynthesis and stomatal conductance responded to water stress by converging, from divergent values among provenances when well-watered, towards similarly low rates under both sun- and shade- treatments. Height growth followed a similar pattern. For stomatal conductance, these differences produced a significant a three-way interaction effect between light- $\times$-water- $\times$-provenance treatments, as provenance-specific differences among well-watered plants in the sun and shade also diminished under water-stress. Otherwise, the significant two-way interactions we report corroborate previous studies that found physiological traits responding to sun-shade transitions to differ among beech provenances (e.g., Tognetti et al. 1998) and likewise those traits affecting water relations in response to drought (Robson et al. 2012; Sánchez-Gómez et al. 2013; Baudis et al. 2014; Pšidová et al. 2015), but hardly any light- $\times$-waterstress interactions affecting water relations or other measured traits (Robson et al. 2009).

\section{How did marginal provenances vs. those from the core range cope with drought stress in sun and shade conditions?}

Instantaneous water use efficiency (IWUE) increases under water-limiting conditions when stomatal conductance limits the photosynthetic rate, as was the case in our Dry treatments. If we consider IWUE the best metric for adaptation to drought stress (Hatfield and Dold 2019), we can say that all of the provenances responded similarly well to water 
limitation by increasing IWUE while still maintaining a positive carbon balance and growth rate (Tognetti et al. 1995; Rose et al. 2009; Sánchez-Gómez et al. 2013; but see Dounavi et al. 2016). The trends in IWUE and $C_{\mathrm{i}} / C_{\mathrm{a}}$ between Wet and Dry treatments followed similar patterns to those found among beech seedlings in earlier studies (Aranda et al. 2012) in showing that even moderate drought causes increased diffusional limitations of $\mathrm{CO}_{2}$, limiting $A_{\text {net }}$ and slowing growth.

Considering hydraulic traits, Montejo-ES from the southern range-margin endured a larger drop in $\Psi_{\text {midday }}$ than the other provenances in Dry conditions, without any apparent penalty to its growth (e.g., $\Psi_{\text {midday }}-2.3 \mathrm{M} \mathrm{Pa}$ vs. $-1.9 \mathrm{M} \mathrm{Pa}$ in other provenances, Fig. 2). The differences between provenances were less pronounced than those previously found under field conditions of drought and high irradiance for saplings in a Spanish common-garden trial, where provenances from central Spain maintained high $A_{\text {net }}$ even at midsummer (Robson et al. 2012). This contrasts with results involving provenances from cooler sites in central Europe, a continental mountain climate (Czechia) and a continental rangeedge (eastern Poland) along with a mild maritime climate (north coastal Germany), which in field trials in both Spain and Czechia had good physiological functionality in early summer but reduced both carbon assimilation and apparent soil-leaf hydraulic conductance $\left(K_{\mathrm{L}}\right)$ by midsummer (Robson et al. 2012; Pšidová et al. 2018). Patterns in $K_{\mathrm{L}}$ between our treatments reflected differences in midday water potential, but we failed to find significant differentiation in $K_{\mathrm{L}}$ between range edge and core provenances under dry conditions, as has previously been reported in provenance trials (Robson et al. 2012). We can only conclude that, across the provenances, drought had a much greater impact than the sun-shade treatment on $K_{\mathrm{L}}$. The three-way interaction effect (Light- $\times$-Water- $\times$-Provenance) on $g_{s}$ that we found can be attributed in part to the response of Montejo-ES which attained similar IWUE under sun and shade in drought conditions by lowering $g_{\mathrm{s}}$ more than other provenances in the Sun treatment (Figs. 1 and S4). This led to an improved IWUE, similar to that reported for Montejo-ES compared to provenances from the core range in a Spanish greenhouse experiment (Sánchez-Gómez et al. 2013). Since the LMA of sun-leaves of this provenance was also the lowest (Fig. 5), it might be expected to have less resistance to $\mathrm{CO}_{2}$ diffusion through the mesophyll and cell walls than the other provenances tested: a hypothesis deserving direct testing.

\section{Was there evidence of a trade-off between growth and stress tolerance resulting in differences reflecting provenance origin?}

The supposed ecological trade-off between growth and stress tolerance (Niinemets 2010; Valladares and Pearcy
2002), leads us to expect the core provenance from Eichelberg-DE to grow fastest and have the highest rates of gas exchange and hydraulic conductance under unstressed summer conditions in our experiment. This was largely the case (Fig. 4), whereby similarly high rates of height growth were maintained by Eichelberg-DE when shade performance is compared with that in the sun, but otherwise differences in growth among provenances under shade conditions were very small or absent.

The two provenances receiving the highest PAR and UV-B irradiances at their origins are Rindelpholz-DE (from $1175 \mathrm{~m}$ a.s.l. elevation at $47.3^{\circ} \mathrm{N}$ latitude) and Montejo-ES (from $1400 \mathrm{~m}$ a.s.l. elevation at $41^{\circ} \mathrm{N}$ latitude). Seedlings from these provenances also had the highest epidermal UVscreening pigments $\left(I_{\text {flav }}\right.$ and $\left.I_{\mathrm{HCA}}\right)$ under shade conditions and early in the experiment (Fig. 3). Shade values might be considered a baseline for $I_{\text {flav }}$, compared with those of seedlings under high irradiances in the sun treatment, where $I_{\text {flav }}$ increased but was similar among the four provenances. This suggests that, in our growing conditions under a roof transmitting solar UV-A but not UV-B radiation, all four provenances were equally able to up-regulate the accumulation of UV-screening compounds in response to high irradiance irrespective of initial baseline differences. These results were consistent with those of non-targeted metabolite profiling of beech provenances, which found higher concentrations of some organic and amino acids (e.g., fumaric and succinic acids or valine and isoleucine), and some secondary metabolites (e.g., kaempferol, caffeic and ferulic acids) in MontejoES compared with northern provenances; Blaviksliarna-SE and Kempten-DE $\left(47^{\circ} 44^{\prime} \mathrm{N}, 10^{\circ} 23^{\prime} \mathrm{E}, 860-900 \mathrm{~m}\right.$ a.s.l) (Aranda et al. 2017). However, it is notable that in both sun and shade, for all provenances except Montejo-ES-Wet, the values of $I_{\text {flav }}$ in the same set of leaves declined over the summer despite increasing PAR (Fig. S3C).

Higher $I_{\text {flav }}$ in Sun than Shade treatments (Fig. 3) constitutes a well-established photoprotective function against high-light stress (Agati et al. 2013), shielding the leaves from the potentially damaging UV-A and UV-B radiation (Burchard et al. 2000). Like flavonoids, HCAs are antioxidants and scavenge ROS (Martinez et al. 2016), and are liable to vary among beech provenances similarly to ascorbate and pigments from the xanthophyll cycle (GarcíaPlazaola and Becerril 2000a, b). The absorption peak of HCAs is in the UV-B spectrum; although it is known from sunflower leaves, where little or no flavonoids accumulate, that HCAs can also effectively screen UV-A radiation in addition to UV-B (Stelzner et al. 2019). A comparison of flavonoid and HCA accumulation in laurel (Ligustrum vulgare) found both drought and high light to stimulate the accumulation of flavonoids but not HCAs, where the accumulation of neither set of compounds had a detectable cost or benefit affecting the rate of carbon assimilation (Tattini 
et al. 2004). Although there was little overall variation in the HCA index among our treatments or provenances, we detected some statistically significant effects (Fig. 3). In Montejo-SE and Eichelberg-DE, more HCAs were accumulated in the sun than shade treatment, compared with no treatment-effects in the other two provenances. On the second measurement date, HCA index was higher in dry than wet treatments. However, both of these effects were small (a difference in the optical index of $<0.1$ ) so their functional importance is likely to be minor.

Metabolomic-screening has found comparatively high leaf quercetin and kaempferol concentrations in Montejo$\mathrm{ES}$, as well as their induction under water stress in Blaviksliarna-SE, compared with those from Kempten-DE (Aranda et al. 2017). However, high intraspecific variability among individual beech seedlings in both primary and secondary metabolism could mask differentiation at the provenance level (Aranda et al. 2018). Nevertheless, the functional relationship between HCAs and flavonoids in leaf tissue layers is interesting to consider, and the possibility to combine metabolomics and optical indices should allow location and function within the leaf to be better differentiated in the future. Despite their partially overlapping roles in UV-screening and antioxidant function, our results suggest that flavonoids and HCAs respond very differently to environmental stimuli, which is consistent with their synthesis from different branches of the phenylpropanoid pathway (Agati et al. 2013).

\section{Did provenances from locations that experience seasonal water stress show better physiological adaptation to drought?}

Blaviksliarna-SE originates from the northern range margin, where cold temperatures and low soil fertility are expected to limit beech growth more than water stress. Hence, we expected seedlings from this provenance to express the weakest response to our water-stress treatments, especially compared with Montejo-ES and Eichelberg-DE with warmer drier origins. However, there were negligible differences in IWUE among the provenances under water stress, and Blaviksliarna-SE maintained as high a $K_{\mathrm{L}}$ as the other provenances and even higher in the shade-dry treatment. Thus, we cannot say that it was less adapted to cope with drought than the other provenances based on our treatments-although its high $K_{\mathrm{L}}$ might eventually result in a higher risk of hydraulic failure, assuming a trade-off between efficiency and resistance to cavitation. This assumption has proved contentious when studying water relations among beech provenances (Aranda et al. 2015; Schuldt et al. 2016; Stojnić et al. 2018). The provenance-dependent differences in leaf length, LMA, and growth-related traits we recorded were larger than those in physiological traits which were consistent among provenances under water stress. This supports previous assertions that morphological traits are more responsive to drought stress than physiological traits related to photosynthesis or photoprotection (García-Plazaola and Becerril 2000b; Valladares and Pearcy 2002).

\section{What are the implications of this experiment and other provenance tests with beech seedlings for the range-wide capacity of beech to cope with climate change?}

Beech provenances have evolved local adaptation and retain relatively high phenotypic plasticity in fitness-related traits despite the fast rebuilding of populations following the last glacial period (Frank et al. 2017; Gárate-Escamilla et al. 2019). In this respect, beech seedlings seem to adjust biomass partitioning to resource availability better than many similar tree species (Schall et al. 2012). This might indicate that the normal shade syndrome of increased relative above-ground allocation is more effectively tempered under drought stress in beech than in less shade-tolerant species (Rosas et al. 2019). Local adaptation tended to differentiate provenances according to water stress in drought-responsive traits, linked to carbon assimilation (Valladares and Pearcy 2002), and to sun-shade conditions in light-responsive traits affecting growth both directly and indirectly (Burchard et al. 2000), although only $g_{\mathrm{s}}$ and LCC responded to both these treatment combinations in a provenance-specific manner.

In nature, the timing of germination and spring bud-burst phenology of beech seedlings differs among populations from west-east as well as north-south (Sánchez-Gómez et al. 2013; Gárate-Escamilla et al. 2019). In our study, we compensated for these differences by stalling the growth of early germinating provenances prior to the experiment, otherwise in the year of study, and subsequent years (unpublished data), the order of spring flush was Rindelpholz-DE, Eichelberg-DE, Montejo-ES, Blaviksliarna-SE (Table S1). Late bud burst when combined with traits conferring drought tolerance, may prove a useful adaptive trait combination to withstand springtime warming together with reduced precipitation. It may also be a coherent strategy to cope with more frequent late spring frosts on migration to higher elevations and northern latitudes.

\section{Conclusions}

The combination of sun-shade and water-stress treatments did not enhance or depress trait responses compared with each of these factors in themselves, with the exception of stomatal conductance. It differed among provenances in wellwatered seedlings and according to sun-shade treatment, but 
converged towards similarly low rates under water stress. Evidence of local adaptation to drought stress (Hypothesis 1) was weak, although Montejo-ES did have lowest hydraulic conductivity and stomatal conductance under the Sun-Dry conditions. Seedlings of Montejo-ES and Rindelpholz-DE from high elevations had higher baseline epidermal UVscreening (Hypothesis 2), suggesting strong inherent photoprotection, but those from Blaviksliarna-SE and EichelbergDE appeared equally able to induce UV-screening during the summer. Eichelberg-DE, from the range core, also had the highest growth rate in the shade treatment (Hypothesis 2), although there was little evidence for a trade-off between growth and stress tolerance, and Blaviksliarna-SE from the northern range edge maintained high photosynthesis and growth through the summer (Hypothesis 3 ) and may be suited to the day length in Helsinki which provides similar conditions to its origin. Contrasting four beech provenances representing core range and marginal populations, the small differences in trait responses to combined water stress and to sun and shade manipulations provides some evidence for local adaptation against a background of high phenotypic plasticity.

Acknowledgements Open access funding provided by University of Helsinki including Helsinki University Central Hospital. This project was initiated during the COST Action E52, "Evaluation of beech genetic resources for sustainable forestry". We are grateful to Gerhard Huber of the Bavarian Office for Forest Seeding and Planting in Teisendorf, and to Rolf Övergaard of the Southern Swedish Forest Research Centre in Alnarp, for supplying the beech nuts. This work was supported by a grant from the Spanish Ministry of Education and Science to the project CLIMHAYA-BOSALIM CGL2007-66066-C04-03/BOS and Juan de la Cierva Fellowships to T.M.R. and D.S.G. The authors are grateful to the Autonomous Community of Madrid (CAM) for permission to work at el Hayedo de Montejo. The research was supported by the University of Helsinki and Academy of Finland decision 116775 to P.J.A, decision 304519 to T.M.R. and Chinese Scholarship Council to F.W. We thank Noora Imberg for helping to do the experimental work.

Author contribution statement FW, TMR, PJA, IA conceived of and designed the study; FW, TMR, DI performed the experiments, FW wrote the first draft under the supervision of TMR, and all authors contributed to the editing of the manuscript.

Funding COST Action E52, "Evaluation of beech genetic resources for sustainable forestry". Spanish Ministry of Education and Science to the project CLIMHAYA-BOSALIM CGL2007-66066-C04-03/BOS and Juan de la Cierva Fellowships to T.M.R. and D.S.G. Academy of Finland decision 116775 to P.J.A, decision 304519 to T.M.R. and Chinese Scholarship Council to F.W.

Data availability All data will be made available in the following repository https://doi.org/10.5281/zenodo.3748854.

\section{Compliance with ethical standards}

Conflict of interest The Authors have no conflicts or interest of competing interests to declare.
Open Access This article is licensed under a Creative Commons Attribution 4.0 International License, which permits use, sharing, adaptation, distribution and reproduction in any medium or format, as long as you give appropriate credit to the original author(s) and the source, provide a link to the Creative Commons licence, and indicate if changes were made. The images or other third party material in this article are included in the article's Creative Commons licence, unless indicated otherwise in a credit line to the material. If material is not included in the article's Creative Commons licence and your intended use is not permitted by statutory regulation or exceeds the permitted use, you will need to obtain permission directly from the copyright holder. To view a copy of this licence, visit http://creativecommons.org/licenses/by/4.0/.

\section{References}

Agati G, Brunetti C, Di Ferdinando M et al (2013) Functional roles of flavonoids in photoprotection: new evidence, lessons from the past. Plant Physiol Bioch 72:35-45. https://doi.org/10.1016/j. plaphy.2013.03.014

Annighöfer P, Petritan AM, Petritan IC, Ammer C (2017) Disentangling juvenile growth strategies of three shade-tolerant temperate forest tree species responding to a light gradient. For Ecol Manag 391:115-126. https://doi.org/10.1016/j.forec o.2017.01.010

Aranda I, Gil L, Pardos JA (2001) Effects of thinning in a Pinus sylvestris $\mathrm{L}$. stand on foliar water relations of Fagus sylvatica $\mathrm{L}$. seedlings planted within the pinewood. Trees 15:358-364. https ://doi.org/10.1007/s004680100109

Aranda I, Gil L, Pardos JA (2005) Seasonal changes in apparent hydraulic conductance and their implications for water use of European beech (Fagus sylvatica L.) and sessile oak [Quercus petraea (Matt.) Liebl] in South Europe. Plant Ecol 179:155-167. https://doi.org/10.1007/s11258-004-7007-1

Aranda I, Rodriguez-Calcerrada J, Robson TM et al (2012) Stomatal and non-stomatal limitations on leaf carbon assimilation in beech (Fagus sylvatica L.) seedlings under natural conditions. Forest Syst 21:405-417. https://doi.org/10.5424/fs/2012213-02348

Aranda I, Cano FJ, Gasco A et al (2015) Variation in photosynthetic performance and hydraulic architecture across European beech (Fagus sylvatica L.) populations supports the case for local adaptation to water stress. Tree Physiol 35:34-46. https://doi. org/10.1093/treephys/tpu101

Aranda I, Sánchez-Gómez D, de Miguel M et al (2017) Fagus sylvatica $\mathrm{L}$. provenances maintain different leaf metabolic profiles and functional response. Acta Oecologica 82:1-9. https://doi. org/10.1016/j.actao.2017.05.003

Aranda I, Sánchez-Gómez D, Cadahia E, Fernandez de Simon B (2018) Ecophysiological and metabolic response patterns to drought under controlled condition in open-pollinated maternal families from a Fagus sylvatica L. population. Environ Exp Bot 150:209221. https://doi.org/10.1016/j.envexpbot.2018.03.014

Archambeau J, Ruiz-Benito P, Ratcliffe S et al (2020) Similar patterns of background mortality across Europe are mostly driven by drought in European beech and a combination of drought and competition in Scots pine. Ag Forest Meteorol 280:107772. https ://doi.org/10.1016/j.agrformet.2019.107772

Arend M, Sever K, Pflug E et al (2016) Seasonal photosynthetic response of European beech to severe summer drought: limitation, recovery and post-drought stimulation. Ag Forest Meteorol 220:83-89. https://doi.org/10.1016/j.agrformet.2016.01.011

Bartlett MK, Scoffoni C, Sack L (2012) The determinants of leaf turgor loss point and prediction of drought tolerance of species 
and biomes: a global meta-analysis: drivers of plant drought tolerance. Ecol Lett 15:393-405. https://doi.org/10.111 1/j.1461-0248.2012.01751.x

Baudis M, Ellerbrock RH, Felsmann K et al (2014) Intraspecific differences in responses to rainshelter-induced drought and competition of Fagus sylvatica L. across Germany. For Ecol Manag 330:283-293. https://doi.org/10.1016/j.foreco.2014.07.012

Bolte A, Czajkowski T, Cocozza C et al (2016) Desiccation and mortality dynamics in seedlings of different European beech (Fagus sylvatica $\mathrm{L}$.) populations under extreme drought conditions. Front Plant Sci 7(751):1-12. https://doi.org/10.3389/fpls.2016.00751

Bontemps A, Lefèvre F, Davi H, Oddou-Muratorio S (2016) In situ marker-based assessment of leaf trait evolutionary potential in a marginal European beech population. J Evol Biol 29:514-527. https://doi.org/10.1111/jeb.12801

Burchard P, Bilger W, Weissenböck G (2000) Contribution of hydroxycinnamates and flavonoids to epidermal shielding of UV-A and UV-B radiation in developing rye primary leaves as assessed by ultraviolet-induced chlorophyll fluorescence measurements. Plant Cell Environ 23:1373-1380. https://doi.org/10.104 6/j.1365-3040.2000.00633.x

Carsjens C, Quynh NN, Guzy J et al (2014) Intra-specific variations in expression of stress-related genes in beech progenies are stronger than drought-induced responses. Tree Physiol 34:1348-1361. https://doi.org/10.1093/treephys/tpu093

Collet C, Lanter O, Pardos M (2002) Effects of canopy opening on the morphology and anatomy of naturally regenerated beech seedlings. Trees 16:291-298. https://doi.org/10.1007/s0046 8-001-0159-x

Dounavi A, Netzer F, Celepirovic N et al (2016) Genetic and physiological differences of European beech provenances (Fagus sylvatica L.) exposed to drought stress. For Ecol Manag 361:226-236. https ://doi.org/10.1016/j.foreco.2015.11.014

Fraaije RGA, ter Braak CJF, Verduyn B et al (2015) Dispersal versus environmental filtering in a dynamic system: drivers of vegetation patterns and diversity along stream riparian gradients. J Ecol 103:1634-1646. https://doi.org/10.1111/1365-2745.12460

Frank A, Pluess AR, Howe GT et al (2017) Quantitative genetic differentiation and phenotypic plasticity of European beech in a heterogeneous landscape: indications for past climate adaptation. Perspect Plant Ecol 26:1-13. https://doi.org/10.1016/j.ppees .2017.02.001

Fréjaville T, Vizcaíno-Palomar N, Fady B, Kremer A, Benito Garzón M (2020) Range margin populations show high climate adaptation lags in European trees. Glob Change Biol 26:484-495. https://doi. org/10.1111/gcb.14881

Gárate-Escamilla H, Hampe A, Vizcaíno-Palomar N et al (2019) Range-wide variation in local adaptation and phenotypic plasticity of fitness-related traits in Fagus sylvatica and their implications under climate change. Global Ecol Biogeogr 1:95. https:// doi.org/10.1111/geb.12936

García-Plazaola JI, Becerril JM (2000a) Photoprotection mechanisms in European beech (Fagus sylvatica L.) seedlings from diverse climatic origins. Trees 14:339-343. https://doi.org/10.1007/PL000 09773

García-Plazaola JI, Becerril JM (2000b) Effects of drought on photoprotective mechanisms in European beech (Fagus sylvatica L.) seedlings from different provenances. Trees 14:485-490. https:// doi.org/10.1007/s004680000068

Garzón MB, Robson TM, Hampe A (2019) Delta TraitSDMs: species distribution models that account for local adaptation and phenotypic plasticity. New Phytol 222:1757-1765. https://doi. org/10.1111/nph.15716

Geßler A, Keitel C, Kreuzwieser J et al (2006) Potential risks for European beech (Fagus sylvatica L.) in a changing climate. Trees 21:1-11. https://doi.org/10.1007/s00468-006-0107-x
Giesecke T, Hickler T, Kunkel T et al (2006) Towards an understanding of the Holocene distribution of Fagus sylvatica L.: the Holocene distribution of Fagus sylvatica. J Biogeogr 34:118-131. https:// doi.org/10.1111/j.1365-2699.2006.01580.x

Gömöry D, Ditmarová L, Hrivnák M et al (2015) Differentiation in phenological and physiological traits in European beech (Fagus sylvatica L.). Eur J Forest Res 134:1075-1085. https://doi. org/10.1007/s10342-015-0910-2

Hatfield JL, Dold C (2019) Water-use efficiency: advances and challenges in a changing climate. Front Plant Sci 10(103):1-14. https ://doi.org/10.3389/fpls.2019.00103

Jump AS, Hunt JM, Peñuelas J (2006) Rapid climate change-related growth decline at the southern range edge of Fagus sylvatica. Global Change Biol 12:2163-2174. https://doi.org/10.111 1/j.1365-2486.2006.01250.x

Kučerová J, Konôpková A, Pšidová E et al (2018) Adaptive variation in physiological traits of beech provenances in Central Europe. iForest 11:24-31. https://doi.org/10.3832/ifor2291-010

Magri D (2008) Patterns of post-glacial spread and the extent of glacial refugia of European beech (Fagus sylvatica). J Biogeography 35:450-463. https://doi.org/10.1111/j.1365-2699.2007.01803.x

Manzanedo RD, Schanz FR, Fischer M, Allan E (2018) Fagus sylvatica seedlings show provenance differentiation rather than adaptation to soil in a transplant experiment. BMC Ecol 18:42. https://doi. org/10.1186/s12898-018-0197-5

Martinez V, Mestre TC, Rubio F et al (2016) Accumulation of flavonols over hydroxycinnamic acids favors oxidative damage protection under abiotic stress. Front Plant Sci 7:838. https://doi. org/10.3389/fpls.2016.00838

Neitzke M, Therburg A (2003) Seasonal changes in UV-B absorption in beech leaves (Fagus sylvatica L.) along an elevation gradient. Forstwissen Centr 122:1-21. https://doi.org/10.104 6/j.1439-0337.2003.02042.x

Niinemets $\ddot{U}$ (2010) Responses of forest trees to single and multiple environmental stresses from seedlings to mature plants: past stress history, stress interactions, tolerance and acclimation. Forest Ecol Manag 260:1623-1639. https://doi.org/10.1016/j.forec o.2010.07.054

Paule L, Krizo M, Pagan J (1984) Genetics and improvement of common beech (Fagus sylvatica L.). Annales Forestales 11:1-26

Piovesan G, Biondi F, Filippo AD et al (2008) Drought-driven growth reduction in old beech (Fagus sylvatica L.) forests of the central Apennines. Italy Global Change Biol 14:1265-1281. https://doi. org/10.1111/j.1365-2486.2008.01570.x

Pšidová E, Ditmarová L, Jamnická G et al (2015) Photosynthetic response of beech seedlings of different origin to water deficit. Photosynthetica 53:187-194. https://doi.org/10.1007/s1109 9-015-0101-x

Pšidová E, Živčák M, Stojnić S et al (2018) Altitude of origin influences the responses of PSII photochemistry to heat waves in European beech (Fagus sylvatica L.). Environ Exp Bot 152:97-106. https://doi.org/10.1016/j.envexpbot.2017.12.001

Pulido F, Castagneyrol B, Rodríguez-Sánchez F et al (2019) Asymmetry in marginal population performance foreshadows widespread species range shifts. bioRxiv. https://doi.org/10.1101/529560

R Core Team (2019) R: a language and environment for statistical computing. Austria, Vienna

Robson TM, Garzón MB, BeechCOSTe52 database consortium (2018) Phenotypic trait variation measured on European genetic trials of Fagus sylvatica L. Sci Data 5:180149. https://doi.org/10.1038/ sdata.2018.149

Robson TM, Rodriguez-Calcerrada J, Sánchez-Gómez D, Aranda I (2009) Summer drought impedes beech seedling performance more in a sub-Mediterranean forest understory than in small gaps. Tree Physiol 29:249-259. https://doi.org/10.1093/treephys/tpn023 
Robson TM, Sánchez-Gómez D, Cano FJ, Aranda I (2012) Variation in functional leaf traits among beech provenances during a Spanish summer reflects the differences in their origin. Tree Genet Genomes 8:1111-1121. https://doi.org/10.1007/s1129 5-012-0496-5

Rodriguez-Calcerrada J, Atkin OK, Robson TM et al (2010) Thermal acclimation of leaf dark respiration of beech seedlings experiencing summer drought in high and low light environments. Tree Physiol 30:214-224. https://doi.org/10.1093/treephys/tpp104

Rosas T, Mencuccini M, Barba J et al (2019) Adjustments and coordination of hydraulic, leaf and stem traits along a water availability gradient. New Phytol 223:632-646. https://doi.org/10.1111/ nph. 15684

Rose L, Leuschner C, Köckemann B, Buschmann H (2009) Are marginal beech (Fagus sylvatica L.) provenances a source for drought tolerant ecotypes? Eur J Forest Res 128:335-343. https://doi. org/10.1007/s10342-009-0268-4

Sabaté S, Gracia CA, Sánchez A (2002) Likely effects of climate change on growth of Quercus ilex, Pinus halepensis, Pinus pinaster, Pinus sylvestris and Fagus sylvatica forests in the Mediterranean region. Forest Ecol Manag 162:23-37. https://doi. org/10.1016/S0378-1127(02)00048-8

Sack L, Holbrook NM (2006) Leaf hydraulics. Annu Rev Plant Biol. 57:361-381. https://doi.org/10.1146/annurev.arplant.56.03260 4.144141

Sánchez-Gómez D, Robson TM, Gascó A, Gil-Pelegrín E (2013) Differences in the leaf functional traits of six beech (Fagus sylvatica L.) populations are reflected in their response to water limitation. Forest Ecol Manag 87:110-119

Scartazza A, Di Baccio D, Bertolotto P et al (2016) Investigating the European beech (Fagus sylvatica $\mathrm{L}$.) leaf characteristics along the vertical canopy profile: leaf structure, photosynthetic capacity, light energy dissipation and photoprotection mechanisms. Tree Physiol 36:1060-1076. https://doi.org/10.1093/treephys/tpw038

Schall P, Lödige C, Beck M, Ammer C (2012) Biomass allocation to roots and shoots is more sensitive to shade and drought in European beech than in Norway spruce seedlings. Forest Ecol Manag 266:246-253. https://doi.org/10.1016/j.foreco.2011.11.017

Schuldt B, Knutzen F, Delzon S et al (2016) How adaptable is the hydraulic system of European beech in the face of climate changerelated precipitation reduction? New Phytol 210:443-458. https:// doi.org/10.1111/nph.13798

Stelzner J, Roemhild R, Garibay-Hernández A et al (2019) Hydroxycinnamic acids in sunflower leaves serve as UV-A screening pigments. Photochem Photobiol Sci 18:1649-1659. https://doi. org/10.1039/C8PP00440D

Stojnić S, Suchocka M, Benito-Garzón M et al (2018) Variation in xylem vulnerability to embolism in European beech from geographically marginal populations. Tree Physiol 38:173-185. https://doi.org/10.1093/treephys/tpx128

Tattini M, Galardi C, Pinelli P et al (2004) Differential accumulation of flavonoids and hydroxycinnamates in leaves of Ligustrum vulgare under excess light and drought stress. New Phytol 163:547-561. https://doi.org/10.1111/j.1469-8137.2004.01126.x

Tegel W, Seim A, Hakelberg D et al (2014) A recent growth increase of European beech (Fagus sylvatica L.) at its Mediterranean distribution limit contradicts drought stress. Eur J Forest Res 133:61-71. https://doi.org/10.1007/s10342-013-0737-7

Tognetti R, Johnson JD, Michelozzi M (1995) The response of European beech (Fagus sylvatica L.) seedlings from two Italian populations to drought and recovery. Trees 9:348-354. https://doi. org/10.1007/BF00202499

Tognetti R, Minotta G, Pinzauti S et al (1998) Acclimation to changing light conditions of long-term shade-grown beech (Fagus sylvatica L.) seedlings of different geographic origins. Trees 12:326-333. https://doi.org/10.1007/PL00009719

Valladares F, Niinemets U (2008) Shade tolerance, a key plant feature of complex nature and consequences. Annu Rev Ecol Evol S 39:237-257. https://doi.org/10.1146/annurev.ecolsys.39.11070 7.173506

Valladares F, Pearcy RW (2002) Drought can be more critical in the shade than in the sun: a field study of carbon gain and photo-inhibition in a Californian shrub during a dry El Nino year. Plant Cell Environ 25:749-759. https://doi.org/10.104 6/j.1365-3040.2002.00856.x

Valladares F, Dobarro I, Sánchez-Gómez D, Pearcy RW (2005) Photoinhibition and drought in Mediterranean woody saplings: scaling effects and interactions in sun and shade phenotypes. J Exp Bot 56:483-494. https://doi.org/10.1093/jxb/eri037

Valladares F, Gianoli E, Gómez JM (2007) Ecological limits to plant phenotypic plasticity. New Phytol 176:749-763. https://doi.org/1 0.1111/j.1469-8137.2007.02275.x

Valladares F, Matesanz S, Guilhaumon F et al (2014) The effects of phenotypic plasticity and local adaptation on forecasts of species range shifts under climate change. Ecol Lett 17:1351-1364. https ://doi.org/10.1111/ele.12348

Wang F (2016) Tutorial: SIOX plugin in ImageJ: area measurement made easy. UVPlants Bull 2016:37-44. https://doi.org/10.19232 /uv4pb.2016.2.11

Publisher's Note Springer Nature remains neutral with regard to jurisdictional claims in published maps and institutional affiliations. 